\title{
Shrimp Cultivation and Coastal Livelihood: A Focus on Bangladesh Coastal Vulnerability
}

\author{
A. H. M. Zehadul Karim ${ }^{1}$ \& Sohela Mustari ${ }^{1}$ \\ ${ }^{1}$ Department of Sociology and Anthropology, IRKHS, International Islamic University Malaysia (IIUM), \\ Gombak, Malaysia \\ Correspondence: A. H. M. Zehadul Karim, Department of Sociology and Anthropology, IRKHS, International \\ Islamic University Malaysia (IIUM), Gombak, Malaysia. E-mail: ahmzkarim@yahoo.com
}

Received: June 18, 2015 Accepted: November 9, 2015 Online Published: November 23, 2015

doi:10.5539/ass.v11n28p109 URL: http://dx.doi.org/10.5539/ass.v11n28p109

\begin{abstract}
Shrimp cultivation has developed rapidly in coastal Bangladesh. Secondary literature provides evidence that to afford an alternative way of livelihood for the locals, shrimp cultivation has been extended widely throughout the coastal areas of Bangladesh. But, the extension of shrimp farming is unable to create work opportunity for the locals in the true sense. In this research, by using a household survey, to know their basic demographic information, it is revealed that though $80 \%$ of the household heads main occupation is fishing and related works only $0.71 \%$ of their main source of fishing is shrimp farm. Moreover, in-depth interviews and focus group discussions disclose that shrimp cultivation of this village is controlled and retained by the rich and outside investors, not by the poor locals. This research also discovers that man-made disasters along with natural disasters are equally responsible for generating vulnerability from shrimp cultivation.
\end{abstract}

Keywords: vulnerability, shrimp cultivation, Bangladesh, livelihoods, man-made disasters

\section{Introduction}

Since the very beginning of human history, people have long been using their coastal areas for multiple purposes; urban resolutions, docking, marine support and agricultural estates are some of the important functions which people have depended upon. These inclinations to coastal use mostly began in the 19th century as part of colonial expansion. Presently, investors are spending money on these coastal settings to expand tourism and increase global trade (Blaikie et al., 2004). Scientific research claims that the usage of coastal areas will increase further in the near future due to its unique natural setting as well as due to human requirements of food and resources which are simply the outcome of increasing population pressure.

Adger et al. (2005) mention that in the near future, 50\% of the world's total population will live within $100 \mathrm{~km}$ of the coastal belt and according to them, these people experience effects of climate change through various natural hazards and man-made obstacles. These obstacles will grind down their resiliency very badly. It is projected in their paper that though at present 10 million people around the world are facing coastal disasters, it will further increase and will reach 50 million by 2080. They censure both climate change effects and population concentration for these natural disasters and for their vulnerable effects (Adger et al., 2005). This will be more devastating in the coastal areas of less developing countries than developed countries. According to Mirza (2003, p. 233):

Developing countries are vulnerable to extremes of normal climatic variability, and climate change is likely to increase the frequency and magnitude of some extreme weather events and disasters. Adaptation to climate change is dependent on current adaptive capacity and the development models that are being pursued by developing countries.

All these natural disasters which are regular in coastal areas have both direct and indirect implications on social life with massive vulnerabilities on the inhabitants. For instance, direct impacts of these disasters damage their infrastructure. Similarly, indirect impacts initiate vulnerabilities by destroying coastal ecosystems and increasing climate change effects, decreasing economic progress and lessening livelihood options. This is how these natural disasters increase overall social vulnerabilities for the coastal community (Adger et al., 2005). 


\section{Literature Review}

Blaike et al. (2004, p. 5) state:

Disasters are a brake on economic and human development at the household level (when livestock, crops, homes, and tools are repeatedly destroyed) and at the national level when roads, bridges, hospital, schools and other facilities are damaged. The pattern of such frequent stresses, brought on by a wide variety of "natural" trigger mechanisms, has often be complicated by human action - both by efforts to palliate the effects of disaster and by the social causation of vulnerability.

Many research in contemporary times claim that among others, aquaculture is one of the major livelihoods and employment options for the Bangladesh coastal rural people (Sohela, 2013; Mustari \& Karim, 2015; Mustari \& Karim, 2012). Though shrimp aquaculture started in 1971, it only became an export production in the 1980s (Azad, Jensen \& Lin, 2009). Before turning into shrimp fields, all lands were used as agro fields by villagers. Many land owners changed to shrimp farming because it was much more suitable for the coastal setting. Additionally, it required very low production costs yet provided huge profits. These shrimp cultivation activities developed swiftly in the coastal regions. According to Azad et al. (2009), Bangladesh coastal regions have around 16,237 acr and 36,109 acr water shrimp and fresh water shrimp, respectively. Apparently, it through they present profitable income sources, they do bring a number of negative consequences on coastal life and livelihood. Mainly, they degrade the quality of mangrove forest and the quality of land. They also reduce the quality of both surface water and ground water. It is true that shrimp culture increases economic opportunities and profit- making for some of the farmers but at the same time, they reduce dramatically the sources of food safety and nourishment for most of the inhabitants.

In some reports, it is said that shrimp agri-business as a profitable trade started its journey in the 1960s and continued through the middle of the 1980s (McMichael, 2011). World Bank and IMF initiated policies under a Structural Adjustment Program which helped to guide shrimp farming in general (VERITE, Fair Labor, n. d.). Indisputably, the shrimp culture industry earns valuable foreign exchange for developing countries and generates jobs across the industry from fry gatherers to growers and processors (Hossain, Uddin, \& Fakhruddin, 2013). Apart from national income, shrimp farming is helpful in providing local employment. Shrimp cultivation succeeded in employing millions of people. It is an attraction for investors as Bangladeshi coastal land and water are very much suitable for shrimp cultivation which requires comparatively small capital to gain huge profit. It can be said that besides agro-climatic situation including suitable land and water resources, cheap human labour and their recruited international agents are equally important (Paul \& Vogl, 2011). It cannot be denied that shrimp cultivation is a good option for increasing economic profit as it helps in reducing poverty and raising the national income. Bangladesh earns around 500 million dollars of foreign currency every year by exporting shrimp which guarantees $3.78 \%$ of its GDP (Nupur, 2010).

Although Bangladesh has 19 coastal districts, shrimp cultivation is developed mostly in the south-western coastal zones of the country. It is estimated that around $80 \%$ of total shrimps come from these zones where both Bagda (Note 1) and Golda (Note 2) shrimps are available. Bagda shrimps are those which are cultivated in rice fields transforming them into shrimp farms. For this type of farming, saline water is essential. Typically, it is found that the owners of Bagda farms reside outside the farms or they lease to the local rich people. On the other hand, Golda shrimps can be cultivated in fresh water ponds and gher. As they require less land and have minimal negative impacts on ecology, they are rapidly becoming widespread among the local people (Nupur, 2010). Usually, coastal people are used to cultivating the shrimps with the rice crop. This is how shrimp farming works as an alternative to bringing resiliency in coastal Bangladesh.

A number of literatures have discussed the benefits of shrimp cultivation in the coastal regions of Bangladesh from broader and national economic perspectives. However, none of them has talked about the social vulnerabilities of the local villagers who live there and struggle to survive because of the shrimp industry. Much of the literature shows, shrimp farming is creating employment opportunities but how it benefits the locals is still not analyzed from the sociological point of view. Apart from this, it was found that few literature discuss the effects of shrimp cultivation from the environment sciences' point of view including degradation of land productivity. However, how this land productivity creates vulnerability in local villagers' livelihood has not been discussed. Moreover, demographic characteristics and shrimp cultivation have a relationship in determining villagers' vulnerability which has not been examined by any previous literature. Thus article is a small attempting in trying to know the vulnerability faced by coastal villagers in relation to shrimp cultivation. 


\section{Research Objectives}

The objectives of this research are:

1) To know the vulnerability faced by coastal people due to natural disasters while maintaining shrimp farming as their livelihood.

2) To know the differences in their vulnerability in doing shrimp farming due to their socio- demographic differences.

\section{Research Questions}

The research questions for this research are:

1) What are the vulnerabilities faced by coastal people due to natural disasters while maintaining shrimp farming as their livelihood?

2) What are the differences in their vulnerability in doing shrimp farming due to their socio- demographic differences?

\section{Methodology}

\subsection{Research Design}

Before designing this research, this author visited the field site informally several times in July 2011. The aim of those informal visits was to learn about the practical field scenario. During those visits, the researcher chatted with the villagers of Gabura Union to learn their experiences regarding the natural disasters throughout their lives. After those field visits this research relied on some secondary sources.

\subsection{Selection of the Study Area}

This research was conducted in a village named Napitkhali located in Gabura Union of Satkhira District of Southwestern Bangladesh. This researcher preferred to work with these coastal people so that their vulnerabilities in their livelihood options, specifically vulnerability in shrimp farming as a livelihood option can be examined.

\subsection{Selection of Respondents}

The purpose of this study is to identify the vulnerabilities faced by coastal people of Bangladesh in continuing shrimp farming as their livelihood despite the natural disasters in their everyday life. In this context, all the basic socio-demographic information of the villagers from the entire Napitkhali village of Gabura Union, Satkhira District was collected. In addition, total of 30 in-depth interviews were conducted with the villagers and the intellectuals. Apart from these three focus group discussions were done to triangulate the data.

\section{Findings}

The general aim of this study is to know the vulnerabilities experienced by the coastal people of Bangladesh in doing shrimp cultivation while facing various natural disasters. For this purpose, a small village named Napitkhali containing 140 households was chosen. This part of this article thus reports the socio-demographic description of the entire village compiled through an extensive survey. The aim of this part is to give brief and a transparent idea about the coastal life in general in rural Bangladesh.

Table 2. Demographic description of Napitkhali villagers

\begin{tabular}{lll}
\hline & $20-29$ & $12.14 \%$ \\
& $30-39$ & $39.29 \%$ \\
Age diversification among household heads & $40-49$ & $20.71 \%$ \\
& $50-59$ & $12.86 \%$ \\
\hline \multirow{2}{*}{ Educational attainment of Napitkhali household heads } & $60-69$ & $5.00 \%$ \\
& $70-79$ & $9.29 \%$ \\
& $80-89$ & $0.71 \%$ \\
\hline
\end{tabular}




\begin{tabular}{lll}
\hline & Secondary level & $9.29 \%$ \\
& Higher secondary and above & $0.71 \%$ \\
\hline & Fishing & $80 \%$ \\
Occupational diversification of household heads & Labourers & $10 \%$ \\
& Business & $2.86 \%$ \\
& Politics & $0.71 \%$ \\
& Housewife & $2.86 \%$ \\
& Boatman & $0.71 \%$ \\
Income among Napitkhali household heads (in Taka) & Retired & $1.43 \%$ \\
& Jobless (due to physical disability) & $1.43 \%$ \\
\hline & $0-4,999$ & $69.99 \%$ \\
& $5,000-9,999$ & $26.44 \%$ \\
Main source of fishing in Napitkhali & 10,000 -above & $3.57 \%$ \\
\hline & River & $20 \%$ \\
& Sea & $14.29 \%$ \\
& Forest Sundarban & $62.14 \%$ \\
& Pond & $0.71 \%$ \\
& Shrimp field & $0.71 \%$ \\
\hline
\end{tabular}

Source: Household survey (2013).

M. Mokhlesur Rahman, the Executive Director of CNRS talked to the researcher about shrimp farming, stating "shrimp farming started in this village in 1980s and now it is in its highest proliferation". He shared his experience of working in this region and said that previously, during crop cultivation period most of the males were engaged in work but after shrimp cultivation they cannot get any job. From this fieldwork in Napitkhali, it is observed that in most cases, the owner has a small group of selected labourers for shrimp farming. According to the villagers, expansion of saline water through natural disasters and shrimp farming means the increase of unemployment level. Therefore, for livelihood purposes, the villagers conveyed that they extract young bagda from the river to sell it to the rich for their shrimp farm.

Md Aiyub Ali is a 28-year old day labourer. He has no formal education and so can only give his signature. Though he is a day labourer and does the work whenever he gets a chance to do so, he expressed fishing and related works as his main profession. He added that as he has no shrimp land of his own, he catches prawn from the river and forest to support and supply the shrimp farm activity. In this regard, he (Md Aiyub Ali) said that as he cannot do work in shrimp cultivation, he chose to collect bagda from the river. By collecting baby prawns, he can meet the requirements of the shrimp market. However, this villager highlighted his anger against the authority because according to him the government does not take care of the poor. They only consider the interests of the rich. He described this:

Like the hatchery owner, the rich people also with the help of government, employed coastguard to stop the fishers. On the other hand, all the permission such as crab collection, fish collection, bagda collection, Goran wood collection from the forest are not permitted. Only we can collect honey and gollpata from the forest. Even though we are doing fishing or other works but mostly this is as a day labour. Because we work it for the rich who is known as mohajon and we get only a part of it. I need to do it because I have no fishing nets and boats to go for fishing.

On the other hand, a very opposing statement came from Md. Mizan Sardar, one of the rich farmers who has more than 100 bigha of shrimp land. He stays outside the village and does shrimp cultivation in Napitkhali. This shrimp farmer stated that:

Inside the embankments, we are bringing the saline water. Here the saline water is not coming naturally all the time. In true sense, we are making channels to bring the saline water from pond, canals and rivers. As this shrimp 
cultivation is very profitable many local and outside rich people, like me, invest their money in this area. We are using the land of local poor villagers with very cheap price.

Md Fajar Ali, a senior member of this village, expressed the uncertainty of their life. He said more about the natural disasters that though historically they experience natural disasters all the time, the effects of these disasters are becoming more severe on their livelihoods than any time before. He further expressed that he is old in age small it is not possible for him to change to a new profession like the other young villagers. He further stated that some young villagers moved to extract forest products or fishing from sea and river but as he is old, after crop cultivation, age factor has stopped him from under talking any new profession.

In the focus group discussion with household heads, five out of six respondents, did not have their own land to do shrimp farming. One of the respondents, Md. Shahid Shardar said that those who have a small portion of shrimp land like him fail to maintain that land regularly. He added that like some other villagers he could not maintain the production cost on that small piece of land and so he has had to sell it to the rich. He added that the rich act like 'land terrorists' who do not consider the well-being of their poor neighbor's at all. Most of those rich people are absentee land lords who do not stay in Napitkhali yet most of the economic profits of this village go into their pockets. All five respondents except Md Shahid Shardar exerted that they have no personal land to do shrimp cultivation. Moreover, they do not have enough money to lease shrimp land from others. For example, among these five, Abdul Majed Hawlader has no shrimp farming land at all. Two of these respondents (Md. Rofiqul Islam and Md Shahid Shardar) had requested the rich. After cyclone Aila, to help them by giving some portion of their unused land. The aim was to use those unused land but the rich people refused to help them.

In the first focus group discussion, the villagers highlighted another reality whereby most of the rich or the investors of shrimp farm do not live in Napitkhali. Mostly they stay in towns and employ their agents to look after the farms. According to Md. Shahidul Islam, the villagers remain deprived as the profits go to other people. Important information came from Md Karim Sardar. He said that as a poor villager his livelihood is so vulnerable that if the supply of fish reduces in the river or forest, he cannot survive. For the other group in the village which does shrimp cultivation, if virus stops prawn cultivation, they can choose tilapia or other salt resistant fish. Md Muzahid Hawlader of this groups similarly talked about shrimp cultivation that though he has no shrimp land, sometimes he needs to work in the shrimp farm as a labourer.

\section{Discussion}

Secondary data show that natural disasters cause a destruction of the existing livelihood options. Blaike et al. (2004, p. 5), for example continue by saying, "disasters are a brake on economic and human development at the household level (when livestock, crops, homes, and tools are repeatedly destroyed)". The claim of secondary literature, including Blaike et al. (2004), is proven when the intellectual interview with M. Mokhlesur Rahman, an Executive Director of CNRS shows that continuous disasters distrupt the common villagers from their regular crop cultivation profession. A group of investors, with the help of the authority, is taking advantage of the impacts resulting from these natural disasters. Water salinity specifically which resulted from cyclones, floods and water logging, decreases land productivity and opens an opportunity for shrimp cultivation. Nevertheless, this opportunity requires significant investment which is not imaginable for the poor villagers who are continuously attacked by natural disasters. In this shrimp industry a new class of investors arises but they are not the local villagers. These outside investors come to this village only to reap the financial benefits but do not consider the betterment of the villagers as most of the time they hire workers from outside. This reality makes it clear that the shrimp industry may bring economic benefits for certain rich investors but has very marginal contributions for the local villagers.

Many research i.e., Badjeck, Allison, Halls and Dulvy (2010) detail the impact of climate change on the coastal household and community people. They claim that with the changed and vulnerable situations villagers look for alternative livelihood options. As is mentioned above, shrimp cultivation is one of the recommended alternative options. Thus, the rich villagers who have enough cultivable lands can generate shrimp cultivation but small farmers or landless farmers are unable to start shrimp cultivation. In addition to all these vulnerabilities, the marginal farmers have had to sell their small piece of land to rich farmers or to outside investors for a cheap price. This selling of property sometimes happens by force or sometimes when there is no other alternative. The secondary data consider aquaculture as one of the major livelihood and employment options for the Bangladesh coastal rural people but the field date show that every one of these coastal villagers is not fortunate in getting shrimp cultivation as their alternative livelihood. For example, Md Aiyub Ali, is an unfortunate villager who has no personal cultivable land for shrimp cultivation, so he needs to extract from nature to supply prawns for shrimp farming. This is how natural disasters along with man-made issues prevent the villagers from shrimp cultivation 
in this village regardless of their demographic variability.

This study also reveals an important finding on shrimp cultivation. Shrimp cultivation is causing long term land degradation. At the beginning when farmers started shrimp farming, they managed to have some benefits but after continuous cultivation the profits from shrimp cultivation seem to dissipate. The reason behind is this saline water logging which creates a kind of bacteria which destroys land productivity for any kind of agricultural work. However, the rich can still cope with shrimp cultivation as they have huge lands so they keep some part of their land in fallow and use the lands for shrimp cultivation by rotation. They are thus not affected by shrimp cultivation like the marginal villagers.

Shrimp cultivation requires larvae but the supply of larvae from natural sources does not remain equal throughout the year. According to the villagers, the number of larvae collectors was less in the past but now that they have very limited options of livelihood, the number of larvae collectors has increased a lot than before. In addition, the collectors are bound to sell the larvae for a cheap price to the shrimp cultivators as no formal market has been established due to their remote location. Field observation exposes that a good number of young boys or child labours are catching larvae for the shrimp farm to support their family and in the process, leave their education entirely. Hence, shrimp farming is creating pressure on the natural supply of larvae and reducing the national education rate.

As mentioned earlier, this research discovers that not only natural disasters but human activities are equally responsible in spreading and depriving coastal villagers from shrimp cultivation. This finding is supported by Bogardi's (2004) existing literature where he mentions that climate change is the result of both human exploitation and natural dynamism. Finally, it can be established that human actions like over-exploitation and natural resource dynamism are together responsible for vulnerabilities resulting from shrimp cultivation as the local villagers' livelihood options.

\section{Conclusion}

Vulnerabilities in shrimp cultivation are the consequence of natural and man-made disasters. A number of respondents in the field work argued the nature of vulnerabilities brought to them primarily by climate change through regular natural disasters. Apart from that, the rich in the society are damaging land productivity by bringing saline water from other sources. Furthermore, these groups of people while benefitting from this farming are doing so at the expense of the environment and society at the same time. It is recommended by this paper to that an integrated policy which can reduce socio-economic damages and increase economic profits for the community is planned in the near future.

\section{References}

Adger, W. N., Hughes, T. P., Folke, C., Carpenter, S. R., \& Rockström, J. (2005). Social-ecological resilience to coastal disasters. Science, 309(5737), 1036-1039. http://dx.doi.org/10.1126/science.1112122

Azad, A. K., Jensen, K. R., \& Lin, C. K. (2009). Coastal aquaculture development in Bangladesh: Unsustainable and sustainable experiences. Environmental management, 44(4), 800-809. http://dx.doi.org/10.1007/s00267 -009-9356-y

Badjeck, M. C., Allison, E. H., Halls, A. S., \& Dulvy, N. K. (2010). Impacts of climate variability and change on fishery-based livelihoods. Marine Policy, 34(3), 375-383. http://dx.doi.org/10.1016/j.marpol.2009.08.007

Blaikie, P., Cannon, T., Davis, I., \& Wisner, B. (2004). At risk: Natural hazards, people's vulnerability and disasters (2nd ed.). London: Routledge.

Bogardi, J. J. (2004). Hazards, risks and vulnerabilities in a changing environment: The unexpected onslaught on human security? Global environmental change, 14(4), 361-365. http://dx.doi.org/10.1016/j.gloenvcha.2004. 06.002

Hossain, M. S., Uddin, M. J., \& Fakhruddin, A. N. M. (2013). Impacts of shrimp farming on the coastal environment of Bangladesh and approach for management. Reviews in Environmental Science and Bio/Technology, 12(3), 313-332. http://dx.doi.org/10.1007/s11157-013-9311-5

McMichael, P. (2011). Development and social change: A global perspective. Pine Forge Press.

Mustari, S., \& Karim, A. H. M. (2012). Impact of salinity on the socio-environmental life of coastal people of Bangladesh.

Mustari, S., \& Karim, A. Z. (2015). Understanding Resiliency in Coastal Areas: A Review Paper from Sociological Perspectives. International Journal of Social Science Studies, 3(3), 123-128. http://dx.doi.org/ 


\subsection{4/ijsss.v3i3.765}

Naser, A. M. S. (2012). Shellfishes of Bangladesh: Shrimp and Prawn. BdFISH Feature. Fisheries Features special reference to Bangladesh.

Nupur, J. M. (2010). Problems and prospects of shrimp farming in Bangladesh. American International University-Bangladesh (AIUB) Business and Economics Working Paper Series.

Paul, B. G., \& Vogl, C. R. (2011). Impacts of shrimp farming in Bangladesh: Challenges and alternatives. Ocean \& Coastal Management, 54(3), 201-211. http://dx.doi.org/10.1016/j.ocecoaman.2010.12.001

Sohela, M. (2013). The Challenges and Coping Strategies of 'Mowal'the Honey collectors of Sundarban. Bangladesh. International Research Journal of Social Sciences, 2(6), 7-11.

VERITE, Fair Labor. (n. d.). Worldwide. Research on Indicators of Forced Labor in the Supply Chain of Shrimp in Bangladesh. Verite, 44 Belchertown Road, Amherst, MA 01002 USA.

\section{Notes}

Note 1. Scientific name (Penaeus monodon) (Naser, 2012).

Note 2. Scientific name (Macrobrachium rosenbergii) (Naser, 2012).

\section{Copyrights}

Copyright for this article is retained by the author(s), with first publication rights granted to the journal.

This is an open-access article distributed under the terms and conditions of the Creative Commons Attribution license (http://creativecommons.org/licenses/by/3.0/). 